\title{
Obituary.
}

\section{Prof. J. Symington, F.R.S.}

\section{$\mathrm{T}$} HE death of Prof. Johnson Symington on February 24 has deprived anatomical science of a keen and devoted investigator who has enriched its literature, especially in the domain of topographical anatomy. Born in $\mathrm{I} 85 \mathrm{I}$, he received his early education in Taunton, and his medical training in the University of Edinburgh, where he graduated in medicine in 1877 . There was no doubt as to his choice of a career, and, within a short period after graduation, he became established as an extra-mural lecturer in anatomy in Minto House, Edinburgh. His reputation as an inspiring teacher attracted large numbers of students, and during this period, which extended over fifteen years, he played an important part in the development of anatomical teaching and research in Scotland.

In 1893 Prof. Symington was appointed to the chair of anatomy in Queen's College, Belfast, and for twentyfour years he devoted himself to the interests of the anatomical department and the general university administration in that centre. Shortly after his appointment to the Belfast chair, he was elected a member of the governing body, and from that time onward until his retirement it may be truthfully said that in every matter dealing with college administration his advice and assistance were sought and freely rendered. On the retirement of Prof. John Purser in I901, Prof. Symington was appointed registrar, and in the same year he helped to found the Better Equipment Fund, acting as one of the honorary secretaries. As a fellow of the Royal University of Ireland he acted as examiner, and contributed in no small degree to the work of framing and carrying out the regulations and courses in anatomy. On the passing of the Irish Universities' Act, I908, he became professor of anatomy and registrar in the Queen's University of Belfast. $\mathrm{He}$ was appointed one of the seven commissioners under the Act to frame the Statutes, and one of the eight members of the Joint Committee. The duties of both these offices he carried out most ably. As a member of the University Senate, Academic Council, Faculty of Medicine, etc., he proved himself to be invaluable. In 1916 he succeeded Sir William Whitla as the University representative on the General Medical Council, but his period of service was unfortunately a very brief one, as within less than a year he was stricken down by the illness which led to his retirement.

Prof. Symington's contributions to anatomical literature cover a wide field, mainly dealing, however, with splanchnology, and the anatomy of the central nervous system. In 1903 he described a method to illustrate the relations of the deeper parts of the brain to the surface, and from this time onwards, until the publication of the work in "Quain's Elements of Anatomy," he carried out a series of investigations in cranio-cerebral topography with which his. name will always be associated. The numerous casts, endocranial, endodural, and arachnoid, which he prepared, were of outstanding merit, and the results of these researches have been of the greatest service to all engaged in the subject of cranio-cerebral topography. A set of these casts is now in the Museum of the Royal College of Surgeons, England. He also subjected to a thorough and careful analysis the value of endocranial casts in the study of prehistoric skulls. In September I908, part I, vol. iii. (Neurology) of "Quain's Elements of Anatomy," was brought out by Sir Edward Sharpey Schafer and Prof. Symington, the macroscopic section of this important work being left entirely to the latter. Part 2 of this volume was issued under the same joint editorship in the following year, and in r9r4 there appeared part 2, vol. ii., on Splanchnology, under the sole editorship of Prof. Symington.

The wealth of anatomical material, upon which this valuable work was based, was the result of many years' collection and preparation by the Belfast Anatomical School. An interesting atlas of skiagrams, illustrating the development of the teeth in man, was published by Prof. Symington and Dr. Rankin, and a set of the original slides was presented to the Royal College of Surgeons, England. His most recent work was the preparation of a complete series of plates illustrating sections of the human body, the atlas being designed specially for the use of military hospitals. More than three hundred copies of this atlas were in use during the War, and proved of great service in the localisation and removal of foreign bodies.

Prof. Symington was elected a fellow of the Royal Society in 1903 , president of the Anthropological Section of the British Association in 1903, and president of the Anatomical Society of Great Britain and Ireland, I904-I906. It is truly a record of good and faithful service, forty years of active work in a subject which he loved so much and for the University of which he was such a distinguished member. Nothing gratified Prof. Symington more than the action of his old pupils in Edinburgh and Belfast in raising sufficient funds to endow a prize, the "Symington Prize," to be awarded by the Anatomical Society for research carried out by junior anatomists. He was delighted when the Society made its first award about a year ago. T. H. M.

\section{Hans Geitel.}

BorN at Brunswick in July $\mathbf{1} 855$, Hans Geitel spent his early years at Blankenburg, and at the local secondary school he formed a friendship with Julius EIster that was the dominant note in both their careers. Having studied at the Universities of Heidelberg and Berlin, Geitel gained his Secondary Teacher's Diploma in 1879 , and proceeded to the Secondary School at Wolfenbüttel, where he rose to be senior science master in 1896 . Elster became associated with the same school in $\mathbf{r} 88 \mathbf{I}$, and lived until his marriage at Geitel's home. After his mother's death, Geitel joined his friend, and they built themselves a house with a wellequipped laboratory. Here they laboured until Elster's death in 1920 , followed soon afterwards by that of Mrs. Elster. Left alone, Geitel arranged for his cousin to keep house for him, and in July 1922 he married her. NO. 2838 , VOL. I I 3 ] 